\title{
The Role of Vascular Endothelial Growth Factor Gene Polymorphisms in Recurrent Spontaneous Abortions in Saudi Women
}

Afrah Fahad Al-khuriji

"Department of Zoology, King Saud University, Riyadh, 11451, Saudi Arabia

*Corresponding author: Afrah Fahad Al-khuriji, Department of Zoology, King Saud University, Riyadh, 11451, Saudi Arabia, Tel: 966555878216; E-mail: Aalkhuriji@ksu.edu.sa

Received date: February 21, 2017; Accepted date: March 04, 2017; Published date: March 10, 2017

Copyright: ( 2017 Al-khuriji AF. This is an open-access article distributed under the terms of the Creative Commons Attribution License, which permits unrestricted use, distribution, and reproduction in any medium, provided the original author and source are credited.

\begin{abstract}
Vascular endothelial growth factor (VEGF) genes regulate proliferation of vascular endothelial cells, hence, are essential for both physiological and pathological angiogenesis. The aim of the present study was to examine the association between three common VEGF single nucleotide polymorphisms (-583 T/C, -1154 G/A, and $936 \mathrm{C} / \mathrm{T})$ and the risk of RSA in Saudi women. A total of 200 women; 100 with RSA-patient matched with 100 controls were enrolled sequentially. Genotyping was conducted using TaqMan assay in order to detect single nucleotide polymorphism (SNPs) in DNA extracts from blood samples. Results showed that the +936C/T allele of VEGF gene is not associated with increased risk of RSA. On the other hand, polymorphisms within -583T/C and -1154G/A of the promotor region were significantly associated with increased RSA risk. Based on these it can be concluded that polymorphisms of VEGF are associated with increased risk of RSA in Saudi women. Hence VEGF gene polymorphism can be a useful biomarker to predict susceptibility to RSA.
\end{abstract}

Keywords: Genotyping; Pregnancy Loss VEGF; Recurrent of Spontaneous Abortion; -583T/C; -1154G/A

\section{Introduction}

Recurrence of spontaneous abortion (RSA) is a frequent reproductive complication that involves 3 consecutive spontaneous abortions [1]. Numerous etiologic causes including; chromosomal abnormalities, antiphospholipid syndrome, structural uterine abnormalities, endocrine disorders, immunologic factors, bacterial and viral infections, and environmental factors; have been documented as leading causes for RSA [2]. However, the exact underlying molecular vascular pathophysiologic mechanism has been poorly understood.

Genetic variability has been suggested to play a role in RSA, and over one hundred proposed genes were investigated [3]. In addition, there is strong evidence supporting a close relationship between embryonic development and the state of vascularization of the chorionic villi $[4,5]$. Vascular endothelial growth factor (VEGF) is a well-known key regulator in angiogenesis [6]. The VEGF protein family includes VEGF-A (VEGF), VEGF-B, VEGF-C, VEGF-D, placenta growth factor (PGF), and their VEGF receptor family (VEGFR-1/ Flt-1, VEGFR-2/KDR, and VEGFR-3/Flt-4) [7,8].

The VEGF gene is highly polymorphic, and at least 25 different polymorphisms have been identified [9]. Some of these polymorphisms are functional and found to be correlated with variations in the production of VEGF protein [10-13]. Furthermore several studied suggested a diminished immunoreactivity of placental trophoblastic vascular endothelial growth factor (VEGF), in the deciduae endothelium, is associated with spontaneous miscarriages [14]. Therefore, polymorphisms in the VGEF are possibly associated with risk of RSA.

In view of the review summarized above, the aim of the present study was to evaluate the association between three common VEGF single nucleotide polymorphisms, $-583 \mathrm{~T} / \mathrm{C}$ and $-1154 \mathrm{G} / \mathrm{A}$, in the promoter region, and $936 \mathrm{C} / \mathrm{T}$ in the 3 '-untranslated region, and the frequency of occurrence of RSA in Saudi women.

\section{Materials and Methods}

\section{Participants}

Participants were 200 women age (18-45 years), with un-explained RSA, consecutively referred to King Khaled University Hospital abortion clinic, Saudi Arabia. All Participants were attending the clinic for routine check-up. The protocol of the present study was approval by the IRB at King Khalid University Hospital and Ethical Committee of King Saud University. All participants signed an informed consent with their approval to participate in the study.

\section{Study design}

A prospective case-controlled design was conducted using two female groups. Patients with unexplained reoccurrence of spontaneous abortion (RSA) were identified sequentially as cases group, hence designated as RSA-group. A second group, matched with age and BMI, served as control group. The inclusion and exclusion criteria for both groups were outlined as follows:

RSA-Group: A hundred women age (18-45) years and BMI (25-30) with unexplained RSA attending the outpatient clinics for abortion, at the Department of Obstetrics and Gyneacology at the King Khalid University Hospital, Riyadh or other hospitals, consecutively referred. The inclusion criterion is; minimum of three RSA. Women with RSA in whom the causes of abortion were known, were excluded by performing anatomical, hormonal, and chromosomal tests. Infection tests for toxoplasma, cytomegalovirus, rubella virus, hepatitis B and C viruses, HIV carried out on these females. In addition women with 
Page 2 of 4

RSA with autoimmune causes, including anti-cardiolipin antibody also excluded from the study.

Control Group: The control group consisted of 100 healthy Saudi females age (18-45) and BMI (25-30), with no history of abortion, with at least two successful pregnancies who were recruited from King Khalid University Hospital.

\section{DNA Quantification and Extraction}

Blood samples $(8 \mathrm{ml})$ for DNA were withdrawn by venepuncture from both groups, in tubes containing anti-coagulant EDTA. The blood centrifuged at $3500 \mathrm{rpm}$ for ten minutes, to separate the plasma from the cells and the buffy coat. The plasma, buffy coat and cells were carefully separated and the plasma stored at $-80^{\circ} \mathrm{C}$ until required for analysis. DNA was extracted from whole blood using pure gene DNA purification kit. The concentration and purity of each DNA sample was determined using the Nano Drop 2000 Spectrophotometer. From each sample $100 \mu \mathrm{l}$ working DNA $(50 \mathrm{mg} / \mu \mathrm{l})$ will be labelled and stored at $4^{\circ} \mathrm{C}$ or $-20^{\circ} \mathrm{C}$.

\section{Genotyping Assays}

TaqMan assay was used to detect SNPs in DNA extracted from samples. Specific primers and probes for the TaqMan genotyping method were available from Applied Bio systems for both SNPs and were used according to manufacturer's instructions. Briefly, this protocol provides instructions for real-time reverse transcription-PCR (real-time RT-PCR) using TaqMan Gene Expression Assays and TaqMan Non-coding RNA Assays. Each assay has a specific probe labelled with a unique fluorescent dye, resulting in different observed colors for each assay [15].

\section{Statistical analysis:}

Descriptive measures and correlation matrix were generated to describe the bivariate linearity among variables of interests by Pearson Product moment correlation (r). Chi square test was carried out to determine the difference in frequencies of the patient and control groups. The odd ratio's was calculated to examine the association between genotype and the phenotype characteristics. P value of $(0.05)$ was adopted as the level of significant. All statistical analysis was conducted using SPSS program version 20.

\section{Results}

The results of Chi square test showed that there were no significant ( $p>0.05)$ association between the +936C/T (rs3025039) allele of VEGF gene and increased risk of RSA (Table 1). On the other hand, two VEGF promotor region alleles (-583T/C (rs3025020) and -1154G/A ( $r$ 1570360) were significantly $(\mathrm{p}<0.05)$ associated with increased RSA risk (Tables 2 and 3 ).

\begin{tabular}{|c|c|c|c|c|c|c|}
\hline \multicolumn{7}{|c|}{ VEGF (+936) C/T (SNP NO.: rs3025039) } \\
\hline \multirow{2}{*}{$\begin{array}{c}\text { Genotyp } \\
\text { e }\end{array}$} & $\begin{array}{c}\text { Control } \\
\text { No. (\%) }\end{array}$ & $\begin{array}{c}\text { Patients } \\
(\%)\end{array}$ & \multicolumn{4}{c|}{ Control vs. Patients } \\
\cline { 5 - 7 } & OR & Cl & X2 & p-value \\
\hline CC & $74(74 \%)$ & $67(73 \%)$ & 0.71 & $0.39-1.31$ & 1.178 & 0.277 \\
\hline CT & $20(20 \%)$ & $24(24 \%)$ & 1.26 & $0.65-2.47$ & 0.466 & 0.494 \\
\hline TT & $6(6 \%)$ & $9(3 \%)$ & 1.55 & $0.53-4.53$ & 0.649 & 0.42 \\
\hline
\end{tabular}

\begin{tabular}{|c|c|c|c|c|c|c|}
\hline Total & 100 & 100 & & & & \\
\hline \multirow{2}{*}{ Allele } & \multirow{2}{*}{$\begin{array}{l}\text { Control } \\
\text { (Freq) }\end{array}$} & \multirow{2}{*}{$\begin{array}{l}\text { Patients } \\
\text { (Freq) }\end{array}$} & \multicolumn{4}{|c|}{ Control vs. Patients } \\
\hline & & & OR & $\mathrm{Cl}$ & $x^{2}$ & p-value \\
\hline C & 0.84 & 0.79 & 0.72 & $0.36-1.42$ & 0.914 & 0.339 \\
\hline $\mathrm{T}$ & 0.16 & 0.21 & 1.4 & $0.80-2.43$ & 1.4 & 0.236 \\
\hline
\end{tabular}

Table 1. The genotype and allele frequencies of VEGF (+936) C/T

\begin{tabular}{|c|c|c|c|c|c|c|}
\hline \multicolumn{7}{|c|}{ VEGF (-583) T/C (SNP NO.: rs3025020) } \\
\hline \multirow{2}{*}{$\begin{array}{c}\text { Genotyp } \\
\text { e }\end{array}$} & \multirow{2}{*}{$\begin{array}{l}\text { Control } \\
\text { No. (\%) }\end{array}$} & \multirow{2}{*}{$\begin{array}{c}\text { Patients } \\
(\%)\end{array}$} & \multicolumn{4}{|c|}{ Control vs. Patients } \\
\hline & & & OR & $\mathrm{Cl}$ & $x^{2}$ & p-value \\
\hline TT & $15(15 \%)$ & $2(2 \%)$ & 0.12 & $0.03-0.52$ & 10.86 & 0.009 \\
\hline $\mathrm{TC}$ & $65(65 \%)$ & $70(70 \%)$ & 1.26 & $0.69-2.27$ & 0.57 & 0.45 \\
\hline $\mathrm{CC}$ & $20(20 \%)$ & $28(28 \%)$ & 1.56 & $0.81-3.00$ & 1.754 & 0.185 \\
\hline Total & 100 & 100 & & & & \\
\hline \multirow{2}{*}{ Allele } & \multirow{2}{*}{$\begin{array}{c}\text { Control } \\
\text { (Freq) }\end{array}$} & \multirow{2}{*}{$\begin{array}{c}\text { Patients } \\
\text { (Freq) }\end{array}$} & \multicolumn{4}{|c|}{ Control vs. Patients } \\
\hline & & & OR & $\mathrm{Cl}$ & $x^{2}$ & p-value \\
\hline $\mathrm{T}$ & 0.475 & 0.37 & 0.65 & $0.40-1.04$ & 3.181 & 0.047 \\
\hline $\mathrm{C}$ & 0.525 & 0.63 & 1.63 & $0.98-2.71$ & 3.575 & 0.058 \\
\hline
\end{tabular}

Table 2. The genotype and allele frequencies of VEGF (-583) T/C

\begin{tabular}{|c|c|c|c|c|c|c|}
\hline \multicolumn{7}{|c|}{ VEGF (-1154) G/A (SNP NO.: rs1570360) } \\
\hline \multirow{2}{*}{$\begin{array}{c}\text { Genotyp } \\
\text { e }\end{array}$} & \multirow{2}{*}{$\begin{array}{l}\text { Control } \\
\text { No. (\%) }\end{array}$} & \multirow{2}{*}{$\begin{array}{l}\text { Patients } \\
(\%)\end{array}$} & \multicolumn{4}{|c|}{ Control vs. Patients } \\
\hline & & & OR & $\mathrm{Cl}$ & $x^{2}$ & p-value \\
\hline GG & $70(70 \%)$ & $3(3 \%)$ & 0.01 & $0.05-0.95$ & 96.84 & 0.001 \\
\hline GA & $21(21 \%)$ & $64(64 \%)$ & 6.69 & $3.56-12.6$ & 37.831 & 0.005 \\
\hline AA & $9(9 \%)$ & $33(33 \%)$ & 4.98 & $2.23-11.1$ & 17.36 & 0.003 \\
\hline Total & 100 & 100 & & & & \\
\hline \multirow{2}{*}{ Allele } & \multirow{2}{*}{$\begin{array}{l}\text { Control } \\
\text { (Freq) }\end{array}$} & \multirow{2}{*}{$\begin{array}{l}\text { Patients } \\
\text { (Freq) }\end{array}$} & \multicolumn{4}{|c|}{ Control vs. Patients } \\
\hline & & & OR & $\mathrm{Cl}$ & $x^{2}$ & p-value \\
\hline G & 0.805 & 0.35 & 0.13 & $0.07-0.23$ & 55.74 & 0.001 \\
\hline A & 0.195 & 0.65 & 7.67 & $4.49-13.0$ & 61.21 & 0.005 \\
\hline
\end{tabular}

Table 3. The genotype and allele frequencies of VEGF (-1154) G/A

The results of Chi square test showed that there were no significant ( $p>0.05)$ association between the $+936 \mathrm{C} / \mathrm{T}$ ( $\mathrm{rs3025039)}$ allele of VEGF gene and increased risk of RSA (Table 1). On the other hand, two VEGF promoter region alleles (-583T/C (rs3025020) and -1154G/A ( $r$ 1570360) were significantly $(\mathrm{p}<0.05)$ associated with increased RSA risk (Tables 2 and 3). 


\section{Discussion}

The major findings of the present study showed that the two promoters regions $-583 \mathrm{~T} / \mathrm{C}$ and $-1154 \mathrm{G} / \mathrm{A}$ polymorphisms and allele haplotypes are associated with increased risk of RSA. The gene of VEGF is a member of growth factor family. It encodes a heparinbinding protein, which exists as a disulfide-linked homodimer. This growth factor induces proliferation and migration of vascular endothelial cells, and is essential for both physiological and pathological angiogenesis. Clearly disruption of this gene results in abnormal formation of blood vessel and the subsequent abnormal placental angiogenesis [16,17]. It was reported that VEGA gene is upregulated in many known tumors and its expression is correlated with tumor stage and progression. Furthermore, allelic variants of VEGA gene have been associated with microvascular complications of diabetes 1 (MVCD1), atherosclerosis, cerebrovascular and cancer diseases $[11,18]$.

On the contrary, the findings of the present study regarding the non-significant association of $+936 \mathrm{C} / \mathrm{T}$ polymorphism and allele haplotypes of RSA-women, are in agreements with previously reported [19] who found no association between RSA and the +936 C/T VEGF polymorphisms. Similar results had been published [6]. Despite that other VEGF polymorphisms have been found to be associated with RSA [17]. It is important to realize that these studies comprised women with only two miscarriages whereas our study included only women with three or more miscarriages.

The findings regarding significant association between VEGF promoter region genotype and allele frequencies in RSA-patients while genotype TT as well as the allele $\mathrm{T}$ frequency were remarkably associated with decreased risk to RSA are consistent with previously reported in Bahraini women [20,21]. Here we extended previous findings by analysing the distribution of $5^{\prime}$-UTR of intron $62583 \mathrm{C} / \mathrm{T}$ VEGF polymorphisms in Saudi RSA-women. Based on these extended works it can be generalized that genotypes -1154 AA and GA are significantly more frequent in women with RSA compared with controls wherein the genotype GG is not associated with RSA. The allele $-1154 \mathrm{~A}$, but not $\mathrm{G}$, is associated with increased risk of RSA. Similar findings was reported that showed that the -1154 A allele was increased substantially, when -1154 A/A genotype was considered, in Indian RSA-women [22]. In addition, the frequency of homozygosity of the VEGF-1154 G/A gene was significantly higher among women experiencing recurrent implantation failure, compared with fertile control women. It was concluded that homozygosity of the VEGF $-1154 \mathrm{G} / \mathrm{A}$ gene may be considered a susceptibility factor affecting for recurrent implantation failure [23]. Given recurrent implantation failure shares pathogenic similarities with RSA, VEGF -1154 G/A may play a critical role in RSA. On contrary, Zhang and colleagues reported that there were no association between VEGF -1154 G/A polymorphism and RSA-Asia women, as compared with non-RSA Asian women [24]. However, the results of systematic review and meta-analysis suggested that -1154G/A (rs1570360), +936C/T (rs3025039), and -583T/C (rs3025020) polymorphisms correlated with an elevated risk of RSA, indicating a possible increased risk for RSA with polymorphisms at those 3 sites $[25,26]$.

\section{Conclusion}

The findings of the present study confirmed that polymorphisms in VEGF gene is associated with the presence of increased RSA risk. Hence can be useful biomarkers to predict susceptibility to RSA.
However, additional parameters such as predictive values, sensitivity, specificity, ROC and logistic regression must be considered in the design of future studies in order to establish cause and effect between VEGF geneses and RSA.

\section{Conflict of Interests}

The author has no conflict of interest.

\section{Acknowledgement}

This research project was supported by a grant from the "Research Center of the Female Scientific and Medical Colleges", Deanship of Scientific Research, King Saud University.

\section{References}

1. Pereza N, Ostojić S, Smirčić A, Hodžić A, Kapović M, et al. (2015) The -2549 insertion/deletion polymorphism in the promoter region of the VEGFA gene in couples with idiopathic recurrent spontaneous abortion. J Assist Reprod Genet 32: 1789-1794.

2. Wilcox AJ, Weinberg CR, O'Connor JF, Baird DD, Schlatterer JP, et al. (1988) Incidence of early loss of pregnancy. N Engl J Med 319: 189-194.

3. Rull K, Nagirnaja L, Laan M (2012) Genetics of Recurrent Miscarriage: Challenges, Current Knowledge, Future Directions. Front Genet 3: 34.

4. Te Velde EA, Exalto N, Hesseling P, van der Linden HC (1997). First trimester development of human chorionic villous vascularization studied with CD34 immunohistochemistry. Hum Reprod Oxf Engl 12: 1577-1581.

5. Zygmunt M, Herr F, Münstedt K, Lang U, Liang OD (2003) Angiogenesis and vasculogenesis in pregnancy. Eur J Obstet Gynecol Reprod Biol 110: S10-18.

6. Papazoglou D, Galazios G, Papatheodorou K, Liberis V, Papanas N, et al. (2005) Vascular endothelial growth factor gene polymorphisms and idiopathic recurrent pregnancy loss. Fertil Steril 83: 959-963.

7. Ferrara N, Gerber HP, LeCouter J (2003) The biology of VEGF and its receptors. Nat Med 9: 669-676.

8. Harry LE, Paleolog EM (2003) From the cradle to the clinic: VEGF in developmental, physiological, and pathological angiogenesis. Birth Defects Res. Part C Embryo Today 69: 363-374.

9. Roger MS, D'Amato RJ (2006) The effect of genetic diversity on angiogenesis. Exp Cell Res 312: 561-574.

10. Awata T, Inoue K, Kurihara S, Ohkubo T, Watanabe M, et al. (2002) A common polymorphism in the 5'-untranslated region of the VEGF gene is associated with diabetic retinopathy in type 2 diabetes. Diabetes 51: 1635-1639.

11. Brogan IJ, Khan N, Isaac K, Hutchinson JA, Pravica V, et al. (1999) Novel polymorphisms in the promoter and 5' UTR regions of the human vascular endothelial growth factor gene. Hum Immunol 60: 1245-1249.

12. Watson CJ, Webb NJ, Bottomley MJ, Brenchley PE (2000). Identification of polymorphisms within the vascular endothelial growth factor (VEGF) gene: correlation with variation in VEGF protein production. Cytokine 12: $1232-1235$

13. Mohammadi M, Ollier WER, Hutchinson IV, (2003) A functional association study of VEGF gene promoter polymorphisms with VEGF expression by stimulated pbm cells. Hum Immunol 64: S125.

14. Vuorela P, Carpén O, Tulppala M, Halmesmäki E (2000) VEGF, its receptors and the tie receptors in recurrent miscarriage. Mol Hum Reprod 6: 276-282.

15. Henegariu O, Heerema NA, Dlouhy SR, Vance GH, Vogt PH (1997) Multiplex PCR: Critical parameters and step-by-step protocol. Biotechniques 23: 504-511.

16. Carmeliet P, Ferreira V, Breier G, Pollefeyt S, Kieckens L, et al. (1996) Abnormal blood vessel development and lethality in embryos lacking a single VEGF allele. Nature 380: 435-439. 
Citation: Al-khurji AF (2017) The Role of Vascular Endothelial Growth Factor Gene Polymorphisms in Recurrent Spontaneous Abortions in Saudi Women. J Immuno Biol 2: 120. doi:10.4172/2476-1966.1000120

Page 4 of 4

17. Lee HH, Hong SH, Shin SJ, Ko JJ, Oh D, et al. (2010) Association study of vascular endothelial growth factor polymorphisms with the risk of recurrent spontaneous abortion. Fertil Steril 93: 1244-1247.

18. Awata T, Inoue K, Kurihara S, Ohkubo T, Watanabe M, et al. (2002) A common polymorphism in the 5'-untranslated region of the VEGF gene is associated with diabetic retinopathy in type 2 diabetes. Diabetes 51 : 1635-1639.

19. Traina E, Daher S, Moron AF, Sun SY, Franchim CS, et al. (2011) Polymorphisms in VEGF, progesterone receptor and IL-1 receptor genes in women with recurrent spontaneous abortion. J Reprod Immunol 88: 53-57.

20. Al-Khateeb GM, Mustafa FE, Sater MS, Almawi WY (2011) Effect of the functional VEGFA-583C/T variant on vascular endothelial growth factor levels and the risk of recurrent spontaneous miscarriage. Fertil. Steril 95 2471-2473.

21. Almawi WY, Saldanha FL, Mahmood NA, Al-Zaman I, Sater MS, et al. (2013) Relationship between VEGFA polymorphisms and serum VEGF protein levels and recurrent spontaneous miscarriage. Hum Reprod 28 2628-2635.

22. Aggarwal S, Parven F, Faridi RM, Phadke S, Borkar M, et al. (2011) Vascular endothelial growth factor gene polymorphisms in North Indian patients with recurrent miscarriages. Reprod Biomed Online 22: 59-64.

23. Goodman C, Jeyendran RS, Coulam CB (2008) Vascular endothelial growth factor gene polymorphism and implantation failure. Reprod Biomed Online 16: 720-723.

24. Zhang B, Dai B, Zhang X, Wang Z (2012) Vascular endothelial growth factor and recurrent spontaneous abortion: a meta-analysis. Gene 507: $1-8$.

25. Xu X, Du C, Li H, Du J, Yan X, et al. (2015) Association of VEGF Genetic Polymorphisms with Recurrent Spontaneous Abortion Risk: A Systematic Review and Meta-Analysis. PLoS One 10: e0123696.

26. Zygmunt M, Herr F, Münstedt K, Lang U, Liang OD (2003) Angiogenesis and vasculogenesis in pregnancy. Eur J Obstet Gynecol Reprod Biol 110: S10-18. 